Matgorzata Pegier

Instytut Nauk Historycznych

Uniwersytet Kardynała Stefana Wyszyńskiego w Warszawie

\title{
Sprawy duszpasterskie oraz związane z religijnością i obrzędowością w siedemnastowiecznym Kazimierzu według relacji Stefana Ranatowicza CRL
}

Artykuł prezentuje zagadnienia o charakterze duszpasterskim oraz opis obyczajów i obrzędów religijnych w zakonie kanoników regularnych laterańskich kongregacji Bożego Ciała na podkrakowskim Kazimierzu, a także dotyczących życia siedemnastowiecznego społeczeństwa. Stefan Ranatowicz (1617-1694) był zakonnikiem ze zgromadzenia kanoników regularnych i kronikarzem tejże kongregacji. Opisy zamieszczonych w tekście wydarzeń są barwne i obfitują w liczne szczegóły, nieomawiane w innych źródłach, stanowiąc cenny materiał do dalszych badań nad historią i kulturą siedemnastowiecznego Krakowa i Kazimierza.

The article deals with pastoral issues and presents customs and religious ceremonies in the Corpus Christi Monastery of the Order of Canons Regular of the Lateran at Kazimierz near Cracow, at the same time paintings the image of life of the seventeenth-century society. Stefan Ranatowicz (1617-1694) was a seventeenth-century canon and chronicler of his congregation. Descriptions of events presented in the text are vivid and rich in details - and since they are not discussed in other sources, they make a valuable material for further studies into the history and culture of seventeenth-century Cracow and Kazimierz.

Słow a klucz ow e: historiografia klasztorna, kanonikat regularny, duszpasterstwo, obrzędowość, obyczajowość, kronikarstwo siedemnastowieczne Ke ywo rds: monastic historiography, regular canonry, ministry, religious rituals, customs, seventeenth-century chronicles 
Ksiądz Stefan Ranatowicz (1617-1694) był kronikarzem i dziejopisarzem zakonu kanoników regularnych laterańskich kongregacji Bożego Ciała w Krakowie, na Kazimierzu. Jedyne jego dzieło wydane drukiem w stolicy Małopolski w 1660 r. to żywot bł. Stanisława Kazimierczyka, którego kultu Ranatowicz był gorącym wyznawcą ${ }^{1}$. Poza tym, oprócz Kroniki, pozostał jeszcze, jedynie w wersji rękopiśmiennej, zbiór kazań przechowywany w Bibliotece Uniwersyteckiej w Wilnie ${ }^{2}$ oraz liczne wpisy w księgach metrykalnych, brackich i administracyjno-ekonomicznych, znajdujących się w archiwach parafialnych w Suchej Beskidzkiej i w Wolbromiu, a także w księdze kapituł generalnych (obecnie w Archiwum Klasztoru Bożego Ciała Kanoników Regularnych Laterańskich w Krakowie) ${ }^{3}$. Ponadto udało się ustalić, iż istnieje jeszcze jeden przykład działalności pisarskiej Stefana Ranatowicza, nieuwzględniony w dotychczasowych zestawieniach: katalog biskupów krakowskich, również w postaci rękopisu (obecnie w Bibliotece Zakładu Narodowego im. Ossolińskich we Wrocławiu) ${ }^{4}$. Kodeks ten powstał w pierwszej ćwierci XVI w. w klasztorze. Ksiądz Ranatowicz uzupełnił i opracował informacje w biogramach dawnych oraz uzupełnił kodeks o biogramy biskupów krakowskich z drugiej połowy XVI i pierwszej połowy wieku XVII.

Stefan Ranatowicz urodził się w rodzinie kazimierskich kuśnierzy: Alberta i Elżbiety. Według najnowszych informacji śmierć rodziców kronikarza przypadła na rok 1651 i miała miejsce w czasie ogromnej zarazy, która trwała jeszcze przez cały następny rok i była przyczyną ogromnej ilości zgonów na Kazimierzu i w całej aglomeracji krakowskiej. Kronikarz wychował się i umarł na podkrakowskim Kazimierzu, tu uczęszczał do szkoły parafialnej przy kościele Bożego Ciała, następnie studiował w latach 1635-1636 w Akademii Krakowskiej (na Wydziale Artium), po czym w 1636 r. wstąpił do zakonu

${ }^{1}$ S. Ranatowicz, Jasna pochodnia życia apostolskiego. Żywot świątobliwy Stanistawa Kazimierczyka, Kraków 1660; zob. też A. Witkowska, J. Nastalska, Staropolskie piśmiennictwo hagiograficzne, t. 2, Lublin 2007.

2 Exercicium concionum. Pro Dominicis et Festis totus Anni habitae et conscriptae. Anno Domini 1645. Die 28 Januarii. Pater Stephanus Ranothowic Canonicus Regularis Congregationis Lateranensis professus Cracoviensis, Biblioteka Uniwersytecka w Wilnie, sygn. F3-2155.

3 Acta Capituli Generalis Canonicorum Regularium Lateranensium, Archiwum Klasztoru Bożego Ciała Kanoników Regularnych Laterańskich w Krakowie, b. sygn.

${ }^{4}$ Series archiepiscoporum et episcoporum ecclesiae Cracoviensis, BO, sygn. 620. 
kanoników regularnych laterańskich, do konwentu krakowskiego. Pochowany został w podziemiach kościoła Bożego Ciała. Pełnił wiele funkcji i był zakonnikiem wyróżniającym się pobożnością i wykształceniem, czego dowodem pozostawione przez niego dzieła. Cenili go również przełożeni (szczególnie ksiądz Liberiusz, prepozyt $\mathrm{w}$ latach 1644-1673). Po pobycie w parafiach w Suchej Beskidzkiej i w Wolbromiu w 1659 r. powrócił do Krakowa na prośbę Jacka Liberiusza, który zaczynał właśnie porządkować bibliotekę klasztorną oraz archiwum, spustoszone po najeździe Szwedów. Na stanowisku bibliotekarza i archiwisty Ranatowicz pracował do 1670 r. i najprawdopodobniej wtedy właśnie rozpoczął gromadzenie materiałów do stworzenia historii zgromadzenia.

Kronika jest uznawana za najważniejsze spośród dzieł księdza Stefana Ranatowicza. Mimo że jej wartość została zauważona już przez dziewiętnastowiecznych historyków oraz badaczy literatury i historii sztuki, nie doczekała się dotychczas wydania ani opracowania monograficznego. Publikowano jedynie niewielkie fragmenty, całość natomiast spoczywa w rękopisie w Bibliotece Jagiellońskiej w Krakowie ${ }^{5}$. Nie wiemy, w którym momencie Ranatowicz rozpoczął pracę nad Kronikq i dość trudno to jednoznacznie ustalić. Wiadomo jednak, że pracował nad swym dziełem za czasów prepozytów: Jacka Liberiusza (1644-1673) ${ }^{6}$ i Wiktoryna Wereszczyńskiego (1673-1694) ${ }^{7}$. Jedna ze wzmianek zamieszczonych w samej Kronice sugeruje, że pisał już w $1670 \mathrm{r}^{8}$ Prawdopodobnie pracę rozpoczął po 1658 i kontynuował ją do jesieni 1693 r., czyli niemalże aż do śmierci (kwiecień 1694 r.). Zdecydowanie większa część Kroniki została spisana w klasztorze krakowskim kanoników regularnych, nie jest jednak wykluczone, że poszczególne fragmenty powstały $\mathrm{w}$ innych miejscach pobytu księdza Ranatowicza9.

5 BJ, sygn. 3742 III.

${ }^{6}$ I. Pietrzkiewicz, Biblioteka kanoników regularnych $w$ Krakowie $w$ XVI i XVII wieku, Kraków 2003, s. 58.

7 Ibidem, s. 58.

${ }^{8}$ S. Ranatowicz, Casimiriae civitatis, urbi Cracoviensi confrontatae, origo. In eaque ecclesiarum erectiones et religiosorum fundationes, nec non series, vitae, res gestae praepositorum conventus Canonicorum Regularium Lateranensium s[ancti] Augustini ad Ecclesiam s[acratis]s[imi] Corporis Christi, [Kraków 1658-1693], BJ, sygn. 3742 III, k. 9.

${ }^{9} \mathrm{Na} \mathrm{k.} 35$ zapisał Ranatowicz informację odnoszącą się do 1679 r. i traktującą o sprzedaży świec w kościele w dzień święta Matki Bożej Gromnicznej; zob. ibidem, k. 35ver. Na k. 88 natomiast umieścił żywot Stanisława Kazimierczyka, którego wydanie pochodziło przecież z 1660 r.; zob. ibidem, k. 88ver. 
Pełny łaciński tytuł Kroniki brzmi: Casimiriae civitatis, urbi Cracoviensi confrontatae, origo. In eaque ecclesiarum erectiones et religiosorum fundationes, nec non series, vitae, res gestae praepositorum conventus Canonicorum Regularium Lateranensium s[ancti] Augustini ad Ecclesiam s[acratis]s[imi] Corporis Christi descriptae a Stephano Ranothowicz eiusdem conventus et Ecclesiae Canonico Regul[ari] professo ${ }^{10}$. Sama Kronika jest nie tylko historią zgromadzenia kanoników regularnych w Krakowie. Zawiera także wiele informacji przydatnych przy badaniu dziejów kultury polskiej w XVII w., wspomina o wielu wydarzeniach ogólnopolskich i międzynarodowych tego okresu, z których najsłynniejszym chyba jest opis najazdu Szwedów w roku $1655^{11}$. Stanowi także doskonałe źródło dla badaczy życia codziennego, obrzędów kościelnych, działalności duszpasterskiej w ówczesnym Kazimierzu i Krakowie. Można mówić tu o spojrzeniu na Polskę przez pryzmat Krakowa jako stolicy państwa i kultury. Również sprawy zakonne ujęte są z perspektywy konwentu generalnego, jakim był ośrodek na Kazimierzu i w tym kontekście również widział autor sprawy całego zakonu, a nawet Kościoła w Polsce i na Litwie. Kronika wprawdzie nie jest diariuszem, ale zawiera wzmianki na temat wielu ciekawych wydarzeń, nieobecnych w innych źródłach ${ }^{12}$.

Wiele miejsca poświęcił Ranatowicz sprawom duszpasterskim oraz dotyczącym religijności i obrzędowości. Zagadnienia te nie tworzą jednolitych bloków tematycznych, a wzmianki o nich są rozsiane po całym niemalże tekście Kroniki. Celem tego artykułu nie jest uporządkowanie ani usystematyzowanie tych informacji, ale podkreślenie ich wartości przy prowadzeniu badań nad szeroko pojętą kulturą siedemnastowiecznego Kazimierza i Krakowa.

10 „Początki miasta Kazimierza, położonego naprzeciw miasta krakowskiego. W nich wzniesienie kościołów i założenie klasztorów, a także dzieje, żywoty, czyny prepozytów konwentu Kanoników Regularnych Laterańskich Świętego Augustyna, przy kościele Najświętszego Ciała Bożego, opisane przez Stefana Ranotowicza, kanonika regularnego profesa tego samego konwentu i kościoła” (jeśli nie zaznaczono inaczej, przekłady tekstów źródłowych pochodzą od autorki).

11 Opisanie inkursyjej Szwedów do Polski, i do Krakowa, w: S. Ranatowicz, Casimiriae civitatis, $\mathrm{k} .140-142$.

${ }^{12}$ M. Pęgier, Zjawiska niezwykte $i$ nadprzyrodzone $w$ "Kronice” Stefana Ranatowicza (1617-94) oraz ich rola $w$ spojrzeniu na historie, OiRwP, 58, 2014, s. 139-151. 
Informacje o działalności duszpasterskiej często pojawiają się w kontekście spraw społecznych lub nawet gospodarczych, np. jeśli mowa o zakupach dokonanych przez poszczególnych prepozytów na rzecz klasztoru, niejednokrotnie z przytoczeniem konkretnych sum pieniężnych. Spraw o znaczeniu społeczno-gospodarczym nie zostało w Kronice poruszonych wiele, ale te, które udało się odnaleźć, dają dość dobry pogląd na obyczajowość ludzi żyjących w ówczesnym społeczeństwie, a także pewne wskazówki odnośnie do ich sytuacji materialnej i panujących stosunków.

Pewne opisy kradzieży czy profanacji, jakie miały miejsce na Kazimierzu, oraz tumultów wzniecanych przez studentów, dostarczają też danych o mentalności ówczesnego społeczeństwa. Oddzielny temat stanowi problem odmienności kolonii żydowskiej na Kazimierzu. Kilkakrotnie wspomina Ranatowicz o zajściach między Żydami a krakowskimi żakami, każdorazowo tłumionymi przez wojsko i kończącymi się ukaraniem sprawców ${ }^{13}$. Opisany został choćby przypadek zaatakowania przez grupę studentów orszaku pogrzebowego, co zakończyło się zrzuceniem trumny ze zmarłym z mostu do rzeki ${ }^{14}$. Dość ciekawy jest też wpis na temat zakazu przyjmowania innowierców do Rady Miejskiej w Krakowie, wydany przez biskupa Jana Małachowskiego ${ }^{15}$ oraz historia kobiety, żony jednego z rajców krakowskich, Katarzyny Weiglowej vel Melcherowej ${ }^{16}$, która za przejście na judaizm została w 1539 r. skazana na śmierć przez spalenie ${ }^{17}$. W dwóch miejscach Kroniki znajdują się również informacje o przynoszeniu przez Żydów ziół i przypraw prepozytowi klasztoru Bożego Ciała ${ }^{18}$.

Do tematyki związanej z religią, obrzędowością i działalnością duszpasterską kanoników regularnych oraz z postaciami kolejnych biskupów krakowskich należą opisy części obrzędów czy nabożeństw, a także wizytacji i zarządzeń biskupich. Ponadto pojawia się też temat kaznodziejstwa i działalności różnych bractw, których promotorami lub opiekunami i kapelanami byli zakonnicy. Zdarzają się opisy sytuacji niechlubnych, jak np. kradzieże w kościołach, profanacje lub

13 S. Ranatowicz, Casimiriae civitatis, k. 31ver., 41ver., 138ver.

${ }^{14}$ Ibidem, k. 31ver.

15 Ibidem, k. 56.

${ }^{16}$ Por. W. Urban, Sprawa Malcherowej, w: idem, Dwa szkice z dziejów reformacji, Kielce 1991, s. 25-29, 66-68 (przyp.).

17 S. Ranatowicz, Casimiriae civitatis, k. 19ver; zob. J. Tazbir, Reformacja w Polsce, Warszawa 1993, s. 15.

${ }^{18}$ Ibidem, k. 15ver., 152. 
odstępstwa od wiary, przytoczone niejako ku przestrodze. Ranatowicz wspomina o wielu nabożeństwach, szczególnie dokładnie opisuje procesje w parafii Bożego Ciała i odbywające się w innych kościołach na Kazimierzu i w Krakowie, np. przeniesienie relikwii św. Szymona z Lipnicy. Kronikarz uczestniczył osobiście w tej uroczystości, dlatego mógł podać wiele szczegółów, nieznanych z innych źródeł $\mathrm{z}$ tego okresu.

Dworowi biskupiemu poświęcił Ranatowicz dwa oddzielne ustępy Kroniki. Pierwszy z nich, O biskupach krakowskich ${ }^{19}$, podaje dokonania kolejnych biskupów krakowskich w latach 1143-1348. Dane o dziesięciu biskupach podane są w porządku chronologicznym. Do tematu biskupów powrócił Ranatowicz także we fragmencie De Episcopis Cracoviensibus $^{20}$, gdzie przedstawił sylwetki kolejnych biskupów krakowskich oraz ich dokonania, poczynając od 1328 r., kiedy biskupem był Jan Groth, a kończąc na 1648 r. i biskupie Piotrze Gębickim. W sumie w tym akapicie wymienionych zostało 26 biskupów krakowskich. Kronikarz wielokrotnie oceniał postępowanie konkretnego biskupa (pozytywnie bądź nie). Niepochlebny komentarz towarzyszy np. opisowi działalności biskupa Mateusza, datowanemu na rok 1143, przy czym Ranatowicz powołuje się na relację Krzysztofa Kąckiego oraz Stanisława Bieżanowskiego ${ }^{21}$. Podobnie w niekorzystnym świetle przedstawiony został inny biskup, Paweł Przemakowski. Na marginesie karty, obok ustępu na temat jego dokonañ ${ }^{22}$, kronikarz umieścił nawet adnotację: Episcopus sceleratus ${ }^{23}$. Przy innym biskupie, Fryderyku, podany został, za relacją Miechowity, jego opis zewnętrzny oraz informacje na temat charakteru ${ }^{24}$. Z kolei biskup Ivo oceniony został pozytywnie ${ }^{25}$, podobnie jak Jan Konarski ${ }^{26}$. Często jednak kronikarz poprzestawał na podaniu konkretnych dokonań omawianego biskupa, jak np. odnośnie do działalności Piotra Wysza ${ }^{27}$. Czasem zamieszczał

${ }^{19}$ Ibidem, k. 132.

${ }^{20}$ Ibidem, k. 136-137ver.

${ }^{21}$ Ibidem, k. 132.

22 Ibidem, k. 132ver.

${ }^{23}$ Ibidem.

${ }^{24}$ Ibidem, k. 136ver.

${ }^{25}$ Ibidem, k. 132.

${ }^{26}$ Ibidem, k. 136ver.

27 Petrus dictus Wysch, electus Episcopus Cracoviensis, promotus a Regina. Huius tempore Universitas Cracoviensis et Psalteristae in Ecclesia cathedrali fundantur. Ita Monasterium in Arenis Carmelitarum erigitur. Ita Canonici Regulares Lateranenses fundantur. Visitabat Terram Sanctam, zob. ibidem, k. 136. 
też różne inne ciekawe informacje na temat poszczególnych duchownych, np. zwrócił uwagę na szczególną znajomość języków obcych u Grzegorza Radziwiłła ${ }^{28}$.

Oprócz tych dwóch ustępów, których tytuły wskazują, że poświęcone zostały biskupom krakowskim, wzmianki na temat działalności kolejnych duszpasterzy można napotkać $\mathrm{w}$ wielu innych miejscach Kroniki, choćby przy relacjach z wydarzeń z ich udziałem. Odnaleziona została m.in. informacja na temat roku mianowania równocześnie trzech biskupów krakowskich ${ }^{29}$. Należy nadmienić, że to zestawienie biskupów zamieszczone w Kronice mogło mieć związek ze wspomnianym już wcześniej podobnym katalogiem biskupów krakowskich, również pióra Stefana Ranatowicza.

Niejednokrotnie na kartach Kroniki pojawiają się opisy procesji parafialnych. Relacje te obfitują w liczne szczegóły (odnośnie do porządku procesji, uczestników, tytułów śpiewanych pieśni i hymnów) ${ }^{30}$. Najobszerniej chyba została przedstawiona procesja odbywająca się corocznie w oktawę uroczystości Bożego Ciała od kościoła Świętej Trójcy do kościoła Bożego Ciała na Kazimierzu ${ }^{31}$. Ranatowicz wyliczył zakony, bractwa $\mathrm{i}$ inne grupy biorące udział w uroczystej procesji, niesione sztandary czy też relikwie świętych, ubiory. Kanonik podjął też temat postów $^{32}$ i niektórych obrzędów, jak spowiedź i sposób rozdawania komunii świętej w kościele Bożego Ciała ${ }^{33}$, szczególnych praktyk religijnych (np. wprowadzonego przez prepozyta Marcina Kłoczyńskiego zwyczaju rozdzielania świec w święto Oczyszczenia Matki Bożej) ${ }^{34}$, zjawisk niezwykłych związanych z kultem religijnym. Dobrym przykładem jest tutaj relacja o płaczącym obrazie Matki Bożej w Truskolasach k. Częstochowy. Powołana została wówczas specjalna komisja do zbadania tej sprawy. Jej członkowie uznali obraz za imago gratiosa, po czym został on przeniesiony z namiotu do kościoła ${ }^{35}$. Postanowie-

${ }^{28}$ Ibidem, k. 137.

${ }^{29}$ Circa Annum Domini 1456. Tres Episcopi Cracovienses electi. Joannem Gruszczyński, Episcopum Vladislaviensem, promonit Rex. Joannem Lutecum Regni procancellarium, Canonicum Cracoviensem, elegit Capitulum. Jacobum Sienienski, filium Palatini Sandomiriensis, designavit Summus Pontifex Pius XI, zob. ibidem, k. 11ver.

30 Ibidem, k. 27.

31 Ibidem, k. 48-48ver.

32 Ibidem, k. 6ver., k. 20.

33 Ibidem, k. 139ver.

${ }^{34}$ Ibidem, k. 35ver.

35 Ibidem, k. 149ver. 
nia komisji zostały przytoczone na kartach Kroniki (k. 150ver.-151). Mowa jest również o przenoszeniu obrazów do innych miejscowości, o różnych codziennych i świątecznych obrzędach. Nie pominięto także problemu zawierania małżeństw przez kapłanów w Polsce na przykładzie wydarzeń z $1191 \mathrm{r}^{36}$

Ranatowicz skrupulatnie odnotowywał wszelkie przejawy kultu Stanisława Kazimierczyka. Przekazał m.in. informację o zmianie daty obchodzenia święta patronalnego przez Bractwo Pięciu Ran Pana Jezusa na dzień, w którym również wspominano śmierć błogosławionego zakonnika, przy czym opisał dość obszernie i dokładnie przebieg tej uroczystości ${ }^{37}$. Zawarł też wzmiankę o poleceniu biskupa Andrzeja Trzebickiego, by podczas wojny z Turkami w 1667 r. nawiedzano procesyjnie groby świętych i błogosławionych, podkreślając, iż jednym z celów pielgrzymek był także grób bł. Stanisława Kazimierczyka $^{38}$. Nie zabrakło również opowieści o profanacji Najświętszego Sakramentu, do której doszło, gdy w czasie procesji Hostia wypadła z monstrancji ${ }^{39}$, oraz o kradzieży srebrnej puszki z Najświętszym Sakramentem, przy czym zapis ten zakończony został przestrogą, aby zakrystianie dobrze strzegli kościoła ${ }^{40}$.

Kilkakrotnie pojawia się też sprawa zakazów wydawanych przez biskupa w sprawie zbyt częstego wystawiania Najświętszego Sakramentu (k. 41, 149, 150). Jedna z takich sytuacji zakończyła się odwołaniem do Rzymu i powołaniem specjalnej komisji dla rozstrzygnięcia tej sprawy ${ }^{41}$. Znajdują się w Kronice także uwagi na temat wizytacji poszczególnych zgromadzeń. Często jedynie wspominano o takim wydarzeniu, zdarzają się jednak nieco obszerniejsze relacje, jak np. ta dotycząca wizytacji w zakonie Świętego Ducha (przeprowadzono ją niemalże siłą, a opornych zakonników ukarano) ${ }^{42}$. Niektóre z postanowień biskupich Ranatowicz wyraźnie krytykował (np. wprowadzenie przez biskupa Piotra Gembickiego ponownych egzaminów dla spowiedników) ${ }^{43}$.

36 Ibidem, k. 7.

${ }^{37}$ Ibidem, k. 37.

${ }^{38}$ Ibidem, k. 91.

39 Ibidem, k. 35.

40 Anno Domini 1628, die 14 Julii. Venerabile Sacramentum, cum pixide argentea, de Ecclesia S. Jacobi, Casimiriae, fures abstulerunt. Haec ideo scribuntur, ut sacristiani custodiant Ecclesiam, et bene occlusam teneant, zob. ibidem, k. 35 .

${ }^{41}$ Ibidem, k. 149-149ver.

42 Ibidem, k. 62.

43 Ibidem, k. 149. 
Do spraw religijnych i duszpasterskich bez wątpienia należy też postawa samych duchownych oraz stosunki i sytuacja w klasztorze. Ranatowicz dużą wagę przywiązywał do zachowania reguły zakonnej. Niechętnie odnosił się do odstępstw od obowiązujących przepisów i do rozluźniania dyscypliny. Nie krytykował wprost braci, którzy w jego ocenie żyli nieskromnie lub zbyt dużo uwagi poświęcali sprawom świeckim i ziemskim, lecz nie pomijał też tego tematu jako $\mathrm{w}$ pewnym sensie wstydliwego, a w każdym razie niekorzystnego dla obrazu zgromadzenia. Pisał niepochlebnie o okresach, kiedy mniej dbano o zachowanie reguły zakonnej. Nie pomijał milczeniem również niewłaściwego zachowania niektórych braci, zaznaczając niejednokrotnie, że czyni to „ku przestrodze” (ad cautelam - w łacińskiej części tekstu), aby przykładów takich unikać.

Jednym z okresów, kiedy dość często pojawiały się problemy z zachowaniem dyscypliny i reguł wewnątrzklasztornych, był czas rządów prepozyta Stanisława Manieckiego, którego Ranatowicz dość mocno potępił ${ }^{44}$. Zdarzały się również wykroczenia popełnione przez poszczególnych zakonników, jak np. kradzież kart pergaminowych $\mathrm{z}$ antyfonarza ${ }^{45}$. Także zakrystian kościoła w Krzemieńcu dopuścił się kradzieży pieniędzy złożonych w skarbcu kościelnym ${ }^{46}$. Inny występek dotyczył kradzieży złotego kielicha ze skarbca kościelnego, a dokonał tego jeden z braci konwentu Bożego Ciała, po czym wystąpił z zakonu i zbiegł na Śląsk ${ }^{47}$. Fragment ten obfituje w wiele szczegółów, co wskazuje na bezpośredni dostęp autora do relacji z tych wydarzeń lub też wręcz na jego obecność w tym czasie w klasztorze. Ranatowicz odnotował również przypadek pojawienia się „fałszywego" księdza ${ }^{48}$. Inny kapłan z kolei, określony przez kronikarza jako nieuważny, pozostawił u chorego Najświętszy Sakrament, po czym pojechał $\mathrm{w}$ inne miejsce $\mathrm{w}$ swoich sprawach ${ }^{49}$. Odnaleziono także fragment opisujący problemy z - jak go określił Ranatowicz „swawolnym” proboszczem. Chociaż zachowywał się niestosownie, nie chciał ustąpić z urzędu, pomimo nalegań biskupa ${ }^{50}$. Kolejny przypadek dotyczył księdza Jacka Wyczawskiego. Odprawiając egzorcyzmy,

\footnotetext{
${ }^{44}$ Ibidem, k. 24ver.

45 Ibidem, k. 49.

46 Ibidem, k. 56ver.

47 Ibidem, k. 63.

${ }^{48}$ Ibidem, k. 63-63ver.

${ }^{49}$ Ibidem, k. 6ver.

50 Ibidem, k. 151.
} 
spowodował śmierć trzech kobiet, co Ranatowicz skwitował uwaga, aby funkcji egzorcystów nie powierzać zbyt młodym duchownym ${ }^{51}$.

Wiele spraw wiązało się bezpośrednio lub pośrednio z innymi wspomnianymi w Kronice tematami, tak że czasem trudno postawić wyraźną granicę między jednym zagadnieniem a drugim. Jednak ze względu na zgromadzony w Kronice materiał faktograficzny oraz bogate informacje dotyczące życia społecznego, religijnego czy wręcz obyczajowości ówczesnej epoki stanowi ona ważne źródło do badań nad historią i kulturą nie tylko zgromadzenia kanoników regularnych, ale również Kazimierza i Krakowa. Autor wydaje się wiarygodny, jako że podawał zawsze źródła, na których się opierał, pisząc o czasach dawniejszych, natomiast sprawy sobie współczesne opracowywał albo na podstawie własnej wiedzy i obserwacji, albo za relacją innych osób, niejednokrotnie naocznych świadków, co każdorazowo zaznaczał w tekście lub na marginesach kart.

\section{Bibliografia}

J. Bieniarzówna, J. M. Małecki, Kraków w wiekach XVI-XVIII, wyd. 2 popr. i uzup., Kraków 1994 (Dzieje Krakowa, t. 2)

J. A. Błachut, M. Bartynowski, W pięćsetna rocznicę zatożenia klasztoru Bożego Ciata na Kazimierzu w Krakowie (1405-1905). Szkice dziejów opactwa XX. Kanoników Regularnych Laterañskich, Kraków 1905

F. Klein, Kraków za czasów szwedzkich ( $z$ kroniki ks. Kanoników Regularnych przy kościele Bożego Ciała na Kazimierzu), „Głos Narodu” 27 III 1914, nr 70; 28 III 1914, nr 71

K. Łatak, Ksiadz Stefan Ranatowicz CRL (1617-1694). Barokowy kronikarz i pisarz klasztorny, Kraków 2010

K. Łatak, Odsiecz Wiedeńska w relacji księdza Stefana Ranatowicza CRL, w: Sic erat in fatis. Studia i szkice historyczne dedykowane profesorowi Bogdanowi Rokowi, t. 1, red. E. Kościk i in., Toruń 2012, s. 227-238

J. Mitkowski, Wstęp, w: Stefana Ranatowicza opisanie inkursji Szwedów do Polski i do Krakowa (1655-1657), wyd. J. Mitkowski, Kraków 1958

Opisanie inkursyjej Szwedów do Polski, i do Krakowa, w: S. Ranatowicz, Casimiriae civitatis, urbi Cracoviensi confrontatae, origo. In eaque ecclesiarum erectiones et religiosorum fundationes, nec non series, vitae, res gestae praepositorum conventus Canonicorum Regularium Lateranensium s[ancti]

51 Zob. ibidem, k. 151ver. (Jako nie maja superiorowie exponować ad exorcismos faciendos mtodych). 
Augustini ad Ecclesiam s[acratis]s[imi] Corporis Christi, [Kraków 1658-1693], BJ, sygn. 3742 III, k. 140-142

S. Ranatowicz, Casimiriae civitatis, urbi Cracoviensi confrontatae, origo. In eaque ecclesiarum erectiones et religiosorum fundationes, nec non series, vitae, res gestae praepositorum conventus Canonicorum Regularium Lateranensium s[ancti] Augustini ad Ecclesiam s[acratis]s[imi] Corporis Christi, [Kraków 1658-1693], BJ, sygn. 3742 III

S. Ranatowicz, Jasna pochodnia życia apostolskiego. Żywot świątobliwy Stanistawa Kazimierczyka, Kraków 1660

W. Urban, Sprawa Malcherowej, w: idem, Dwa szkice z dziejów reformacji, Kielce 1991, s. 25-29, przyp. na s. 66-68 (przedruk w: idem, Et haec facienda, et illa non omittenda. Profesor Wactaw Urban w swych dzietach wybranych, Warszawa 2012, s. 63-67)

A. Witkowska, J. Nastalska, Staropolskie piśmiennictwo hagiograficzne, t. 1: Stownik hagiografów polskich, t. 2: Bibliografia hagiografii staropolskiej, Lublin 2007

H. D. Wojtyska, Duchowość kanoników regularnych, „Saeculum Christianum”, 3, 1996, s. $125-130$

\section{Pastoral Issues, together with Religious and Ritual Matters in Seventeenth-Century Kazimierz according to Stefan Ranatowicz C.R.L.}

Stefan Ranatowicz, the author of the Chronicle, was born, brought up and died at Kazimierz near Cracow. He lived in the years 1617-1694, and he lived in the Corpus Christi Monastery of the Order of Canons Regular of the Lateran at Kazimierz near Cracow for most of his life. In 1635-1636 he studied at the Cracow Academy in the Artium Faculty. He left numerous writings, including the most important Chronicle being the example of seventeenth-century monastic historiography. As testified by the comparison with similar texts of that period, Stefan Ranatowicz's Chronicle is on par with such chronicles as that by Samuel Nakielski or Maciej Miechowita, including the correctness of its language, as the text is written partly in Latin, and partly in Polish.

Apart from a chronology of events pertaining to the history of the monastery of the Canons Regular of the Lateran, there are in the Chronicle numerous notes and passages on other various aspects of life. It would be difficult to present them under a specific topic for they are dispersed throughout the whole text, but it has been possible to set apart many fragments describing religious ceremonies, such as solemn processions, achievements of Cracow bishops, monastic discipline, and activities of individual canons, together with some customs of those times. It has been possible to establish, on the 
basis of other sources for the same period, that many colourful and vivid descriptions of events written down by Ranatowicz are the only references to them, as they were not described by other authors.

After a comparison made between the Chronicle and other sources, a thorough analysis of the work and establishment of the number of references to Ranatowicz's text in the scholarly literature on the seventeenth-century history and culture of Cracow in the broad sense of the term, the author concluded that Ranatowicz's Chronicle merits a more close study as it presents a valuable source for the subject.

Małgorzata Pęgier, dr nauk humanistycznych w dziedzinie historii, zatrudniona w Instytucie Nauk Historycznych na Wydziale Nauk Historycznych i Społecznych UKSW w Warszawie. Zainteresowania badawcze: staropolskie kronikarstwo i piśmiennictwo klasztorne, biografistyka i hagiografia, kanonikat regularny w Polsce.

Małgorzata Pęgier, PhD in history, employed at the Institute of Historical Sciences of the Faculty of History and Social Sciences, the Cardinal Stefan Wyszynski University in Warsaw. Her research interests focus on: old-Polish chronicles and monastic writings, biographical writings and hagiography, regular canonry in Poland.

E-mail: m.pegier@uksw.edu.pl 